ارزيابى ميزان انتقال مجدد ماده خشك به دانه ارقام ياييزه كلزا در واكنش به تنش خشكى

حميد جبّارى "، نيراعظم خوشخلق سيما'، غلامعباس اكبرى" و اميرحسين شيرانىراد"

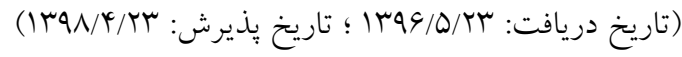

حكيده

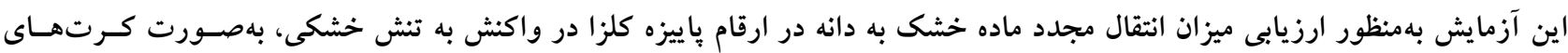

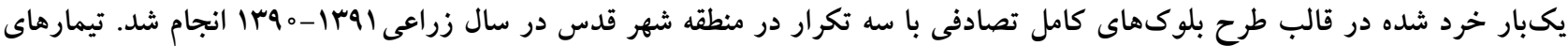

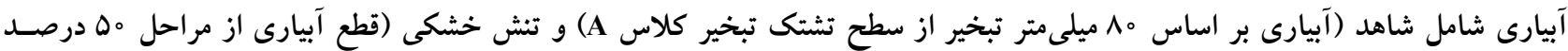

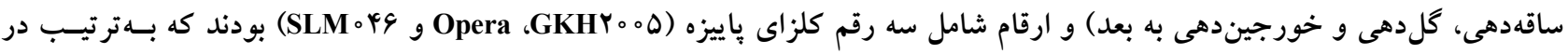
كرتهاى اصلى و فرعى قرار گرفتند. نتايج نشان داد كه تنش خشيكى موجى

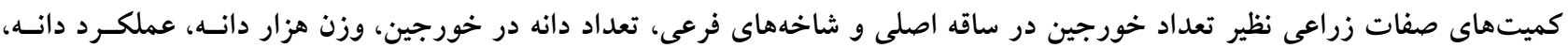

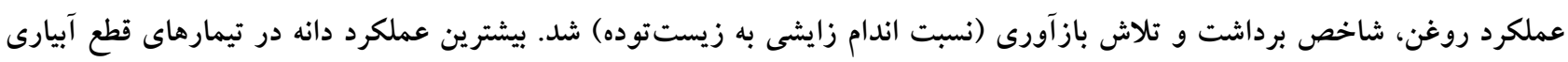

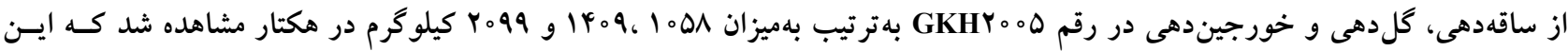

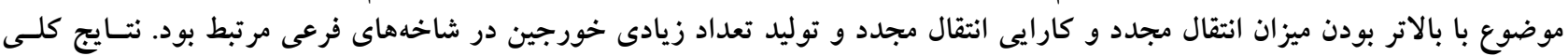

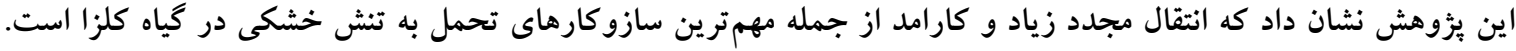

وازههاى كليدى: تعداد خورجين، تعداد دانه، عملكرد دانه، قطع آبيارى

ا و أ. بهترتيب استاديار و استاد مؤسسه تحقيقات اصلاح و تهيه نهال و بذر، سازمان تحقيقات، آموزش و ترويج كشاورزى، كرج، ايران r. دانشيار يزوهشكده بيوتكنولوزى كشاورزى، سازمان تحقيقات، آموزش و ترويج كشاورزى، كرج، ايران r. دانشيار، گروه علوم زراعى و اصلاح نباتات، برديس ابوريحان، دانشخاه تهران، پِاكدشت، ايران

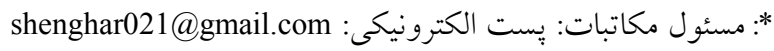




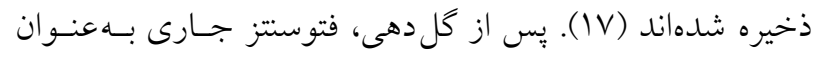

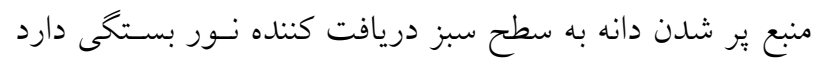

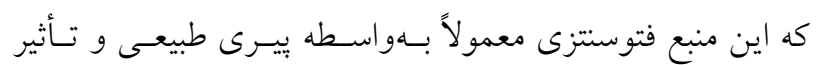

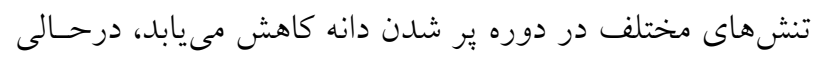

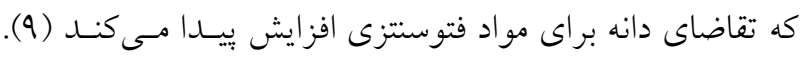

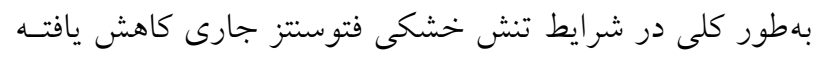

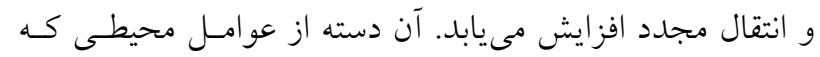

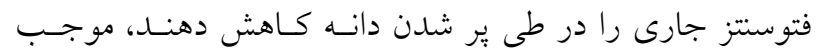

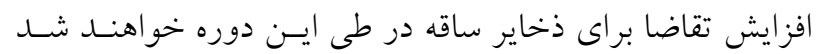

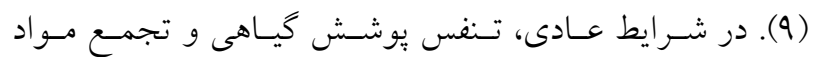
خشك در دانهها، از مهمترين مسـيرهاى مصـرف مـواد هـرورده

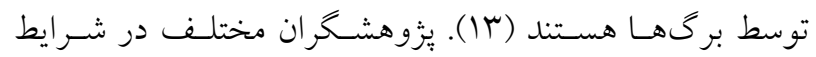

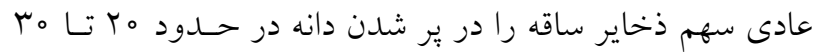

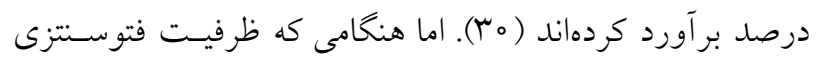
كَاه بهوسيله تنش خشكى كاهش مىيابد، ير شدن دانه بهشدت

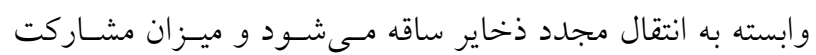

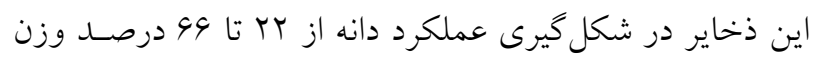

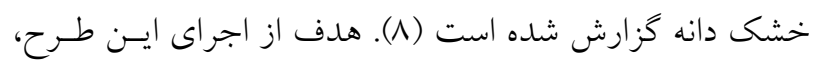

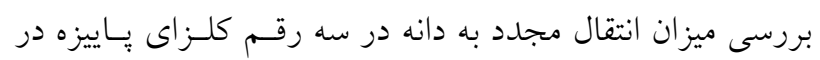
شرايط تنش خشكى بوده است.

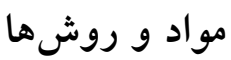
ايـن آزمـايش در سـال زراعسى |q-ه qها، در اسـتان تهـران، در

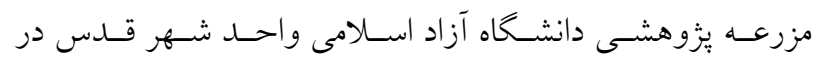

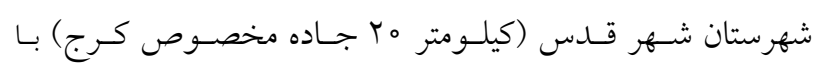

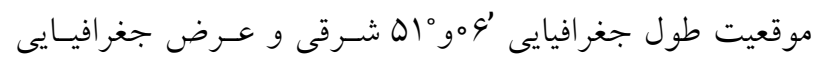

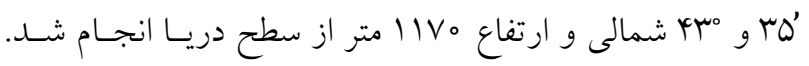

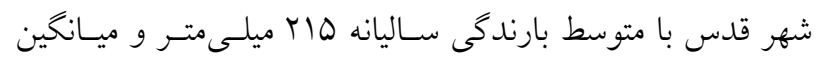

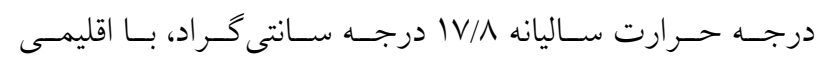

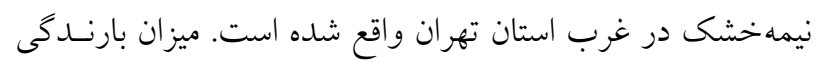

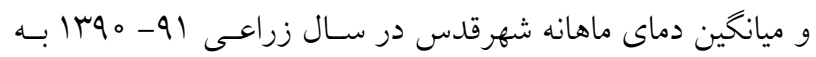
تفكيك در جدول الرائه شده است.

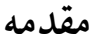

خشكى، مهم ترين عامـل محسدود كنـــه رشـــ كيـاه و توليـدات

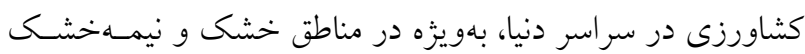

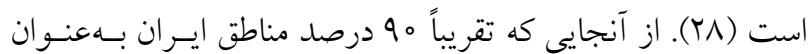

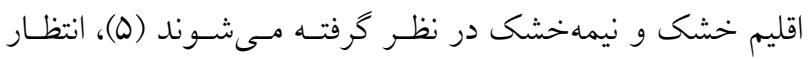

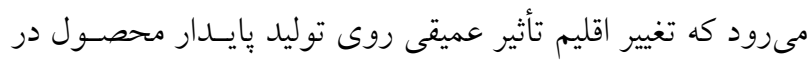

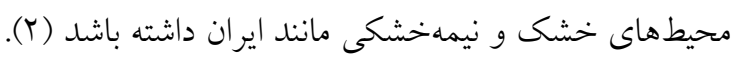

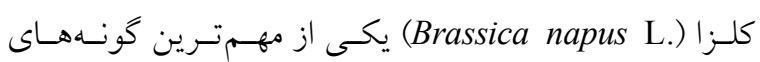

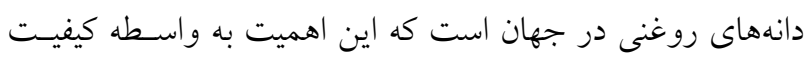

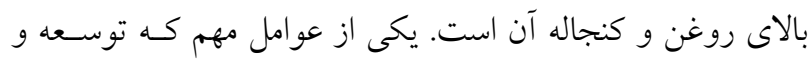

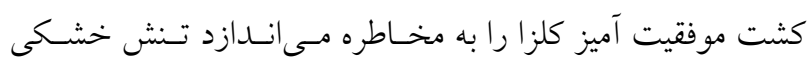

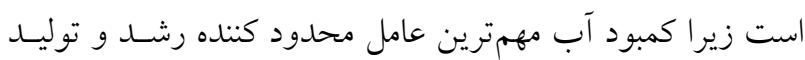

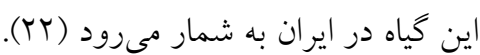
تسـش خشـكى منجــر بــه تغييــرات مضــر در فراينـدهاى فيزيولوزيك و بيوشيمايى در سلولهاى كياهى مىشود و عملكرد

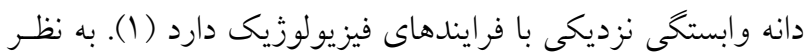
مىرسد افزايش دانش ما از تحمل به تنش خشكى اهميت زيسادى در كشت كياهان و بيدا كردن روشهاى مؤثر براى كاهش اتـرات

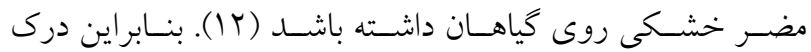
سازو كارهاى فيزيولوزيكى و زراعى تحمل گيـاه در شـرايط تـنش

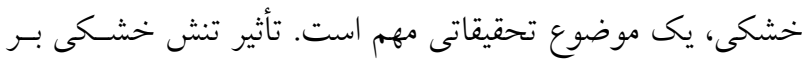

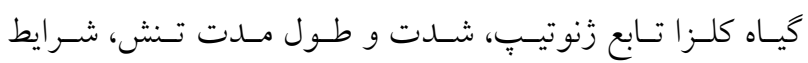

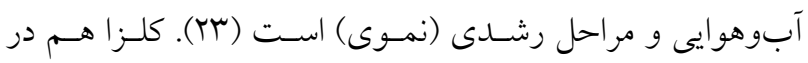

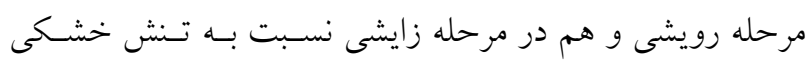

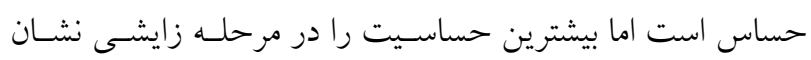

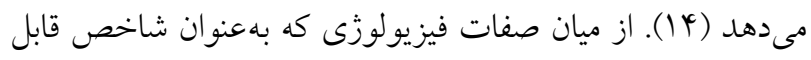

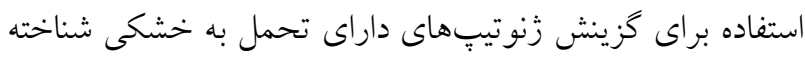

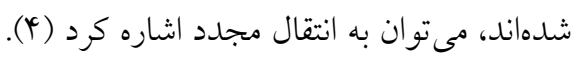
بر شدن دانه تابع سه منبع است كه عبـارتانـــ از: فتوسـتنز

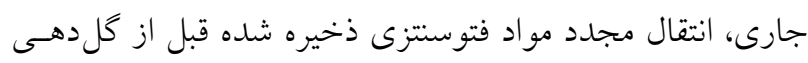

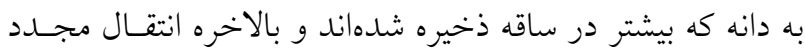

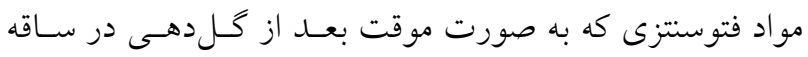




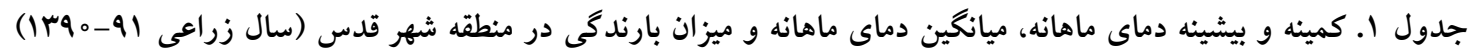

\begin{tabular}{|c|c|c|c|c|c|c|c|c|c|}
\hline خرداد & ارديبهشت & فروردين & اسفند & بهمن & دى & آذر & آبان & مهر & \\
\hline $1 \pi / 0$ & $0 / 9$ & $-\boldsymbol{Y} / 9$ & $-V / T$ & $-9 / 4$ & $-Y / 0$ & $-\mu / 。$ & $r / \varphi$ & $1 Y / 9$ & كمينه دماى ماهانه \\
\hline$M y / 9$ & $r q / 4$ & $r I / 4$ & $19 / 0$ & $1 Y / \Lambda$ & $1 \pi / 0$ & $1 N / T$ & $\mu Y / 0$ & $\mu \mathrm{r} / \Lambda$ & بيشينه دماى ماهانه \\
\hline$T Y / \mu$ & $1 N / T$ & $q / 4$ & $r / q$ & $\varphi / \Delta$ & $\Delta / \mu$ & $9 / 9$ & $1 N / 0$ & $r Q / \varphi$ & $\begin{array}{c}\text { ميانخين دماى ماهانه } \\
\text { مانتى گراد) }\end{array}$ \\
\hline $1 \pi / \mu$ & $r V / r$ & $T Y / 0$ & $\mu_{1 / 1}$ & $T Y / \Lambda$ & $T / l$ & $Y y / 4$ & $\Lambda \mathrm{V} / 0$ & 。 & بارند (ميلى ماهانه \\
\hline
\end{tabular}

جدول r. نتايج آزمون فيزيكى و شيميايى خاك محل آزمايش

\begin{tabular}{|c|c|c|c|c|c|c|c|c|c|}
\hline \multirow{2}{*}{ بافت خاك } & رس & سيلت & شن & \multirow{2}{*}{ يتاسيم قابل جذب } & \multirow{2}{*}{ فسفر قابل جذب } & \multirow{2}{*}{ نيتروزن (\%) } & \multirow{2}{*}{$\mathrm{pH}$} & \multirow{2}{*}{$\begin{array}{c}\mathrm{EC} \\
(\mathrm{dS} / \mathrm{m})\end{array}$} & \multirow{2}{*}{ نمونهبردارى } \\
\hline & & $(\%)$ & & & & & & & \\
\hline لوم & rI & ry & id & $T V Q / \circ$ & $1 T / 0$ & $\circ / 11$ & $V / T$ & $1 / 1 \wedge$ & $\circ-\mu_{0}$ \\
\hline
\end{tabular}

شد. هر كرت آزمايشى شامل جهار خط به طول بــنج متـر بـود و

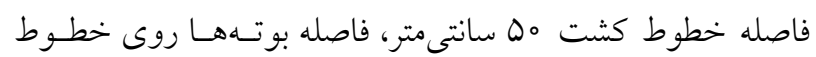
كاشت جهار سانتى متر و تراكم •ه بوته در مترمربع در نظر كرفتسه.

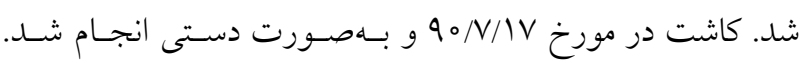
آبيارى در تيمار شاهد و همجنين تيمارهاى تنش خشكى تـا قبـل از اعمال تنش بر اساس هم ميلىمتر تبخير از سطح تشتك تبخيـر كالس A صورت كرفت و مقدار آب مصرفى در هر بـار آبيـارى

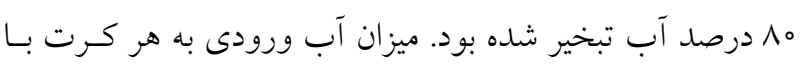

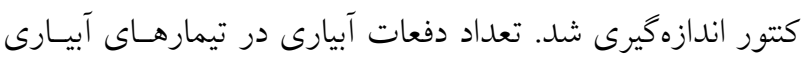

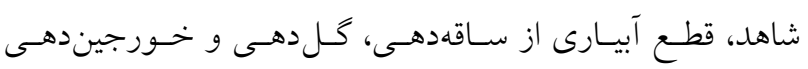

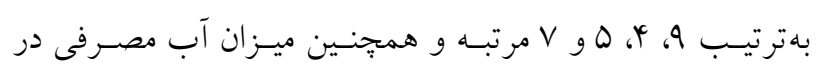

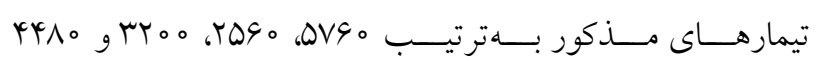
مترمكعب در هكتار بود. بهمنظور جلو گيرى از ورود آب بارندگى

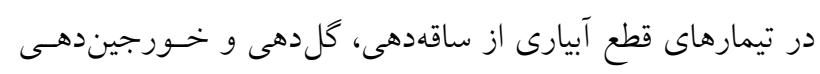
از شلتر (shelter) استفاده شد.

بهمنظور تعيين تعداد خورجين در ساقه اصلى و شاخههـاى فرعى، تعداد هفت بوته از هر كرت آزمايشى در زمان رسـيدكى نعي
خاى محل آزمايش داراى بافت لومى با ميزان هــدايت الكتريكىى

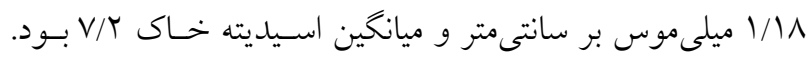

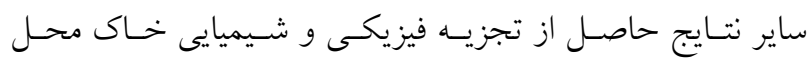
آزمايش در جدول r درج شده است. اين بررسى به صورت آزمايش كرتهاى يكبار خرد شده در قالب طرح بلوكهاى كامل تصادفى بــا سـه تكـــار ارزيـابى شـــ. تيمارهاى آبيارى شامل شاهد (آبيارى بر اساس مه ميلى متر تبخير

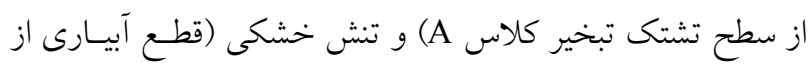

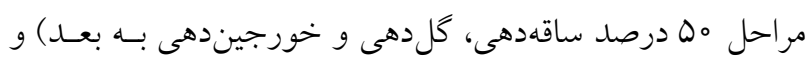

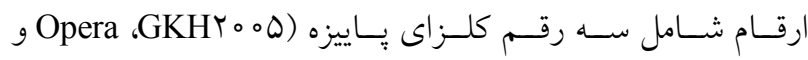
(SLM०49 بودند كه بهترتيب در كرتهاى اصلى و فرعى قـرار كرفتند. بر اساس نتايج تجزيه خاك (جدول r) و توصسيه كـودى، اقدام به كودياشى (كود اوره مW كيلو گرم در هكتار در سه نوبت:

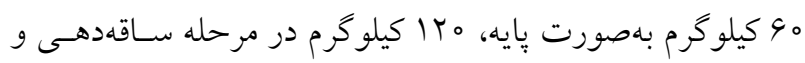
كيلو گرم در مرحله شروع كلدهـى، كـود فسـفات آمونيـوم و

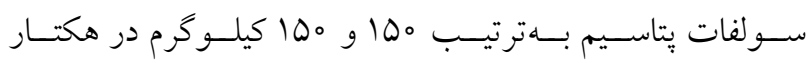

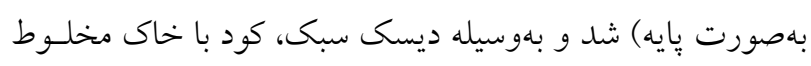


متقابل معنى دار از رويه برشدهى استفاده شد.

\section{نتايج و بحث}

اثر تنش خشكى، رقم و اثر متقابل تنش خشكى × رقم بر ارتفاع

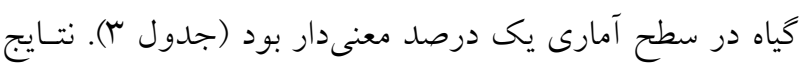

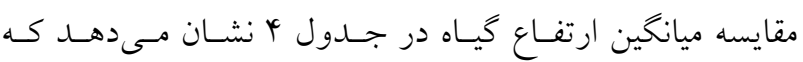

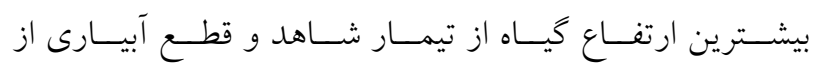

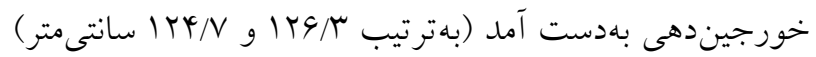

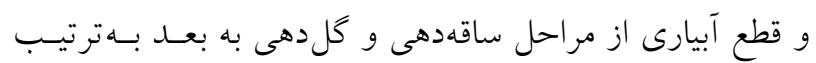

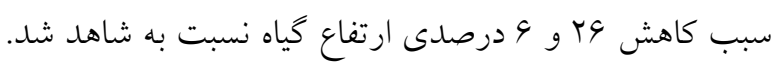

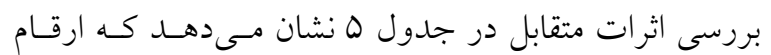

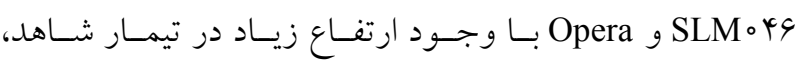

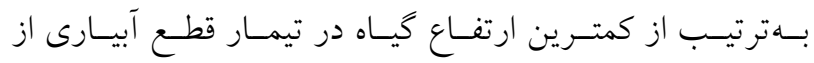

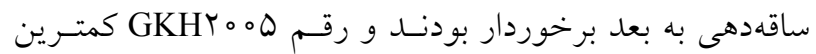

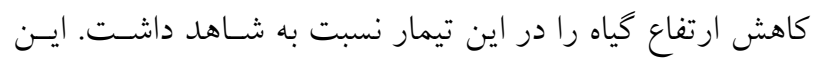

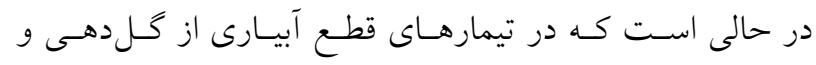

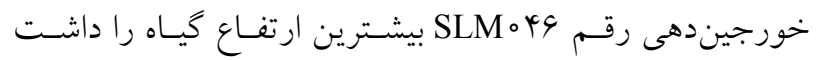

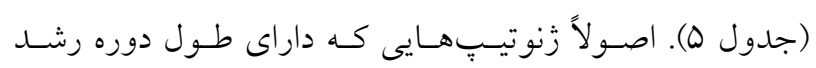

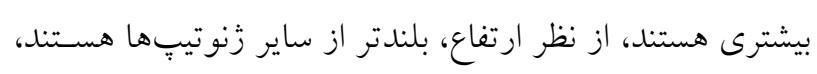

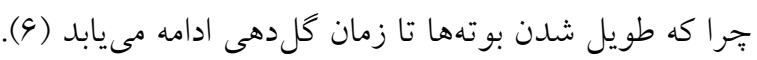

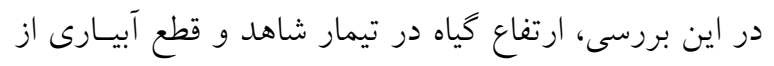

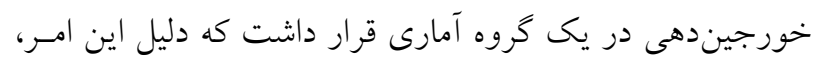

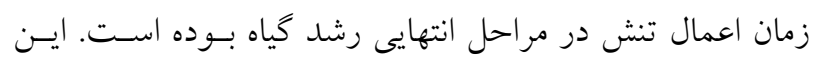

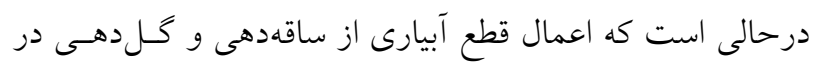
سه رقم كلزاى مورد بررسى سبب كاهش معنى دار ارتفـاع خيـاه در مقايسه با تيمار شاهد شد (جدول هاى هورد كاهش بر ارتفاع كياه كلزا

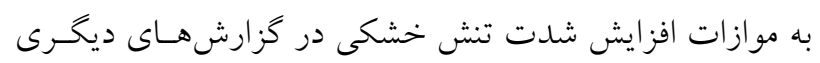

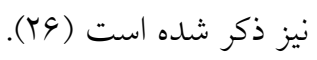

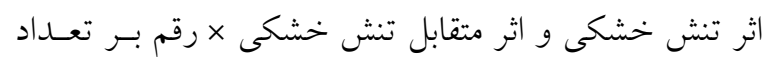
شاخه فرعى در سطح آمارى يك درصد و اثر رقم در سطح بنج

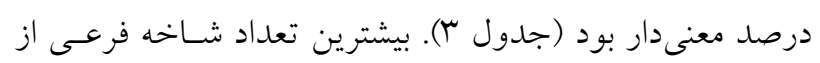

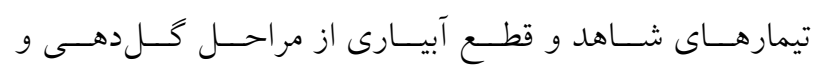

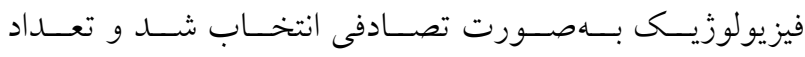

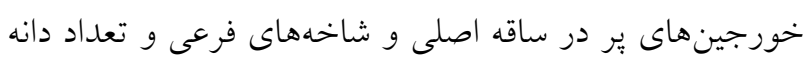

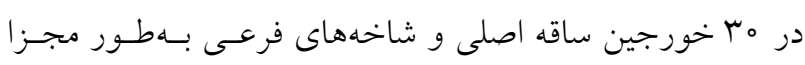

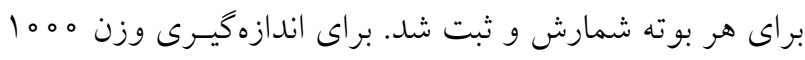

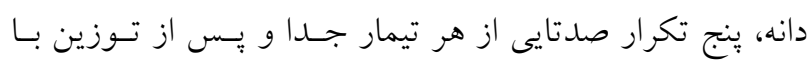

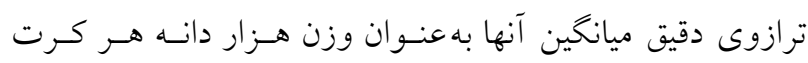

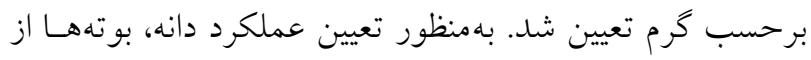

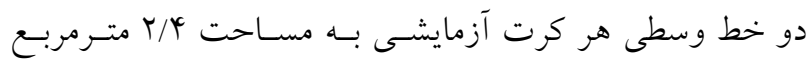

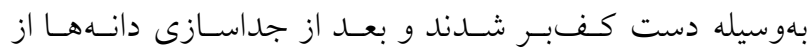

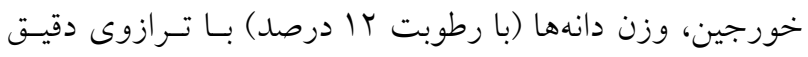
توزين و عملكرد دانه برحسب كيلوكرم در هكتار محاسبه شــد.

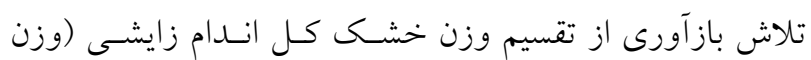
خشى خورجين) بر عملكرد زيست توده (وزن خشك كل ول اندام

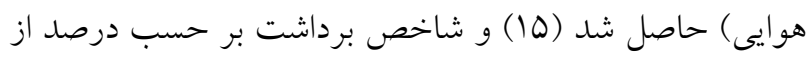

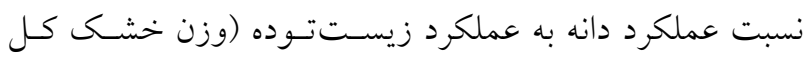

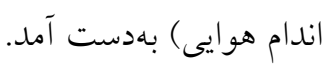

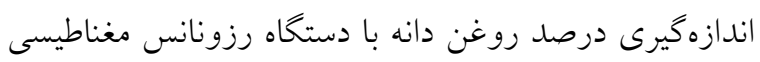

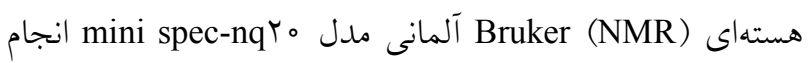

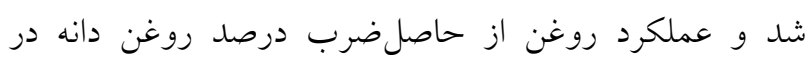

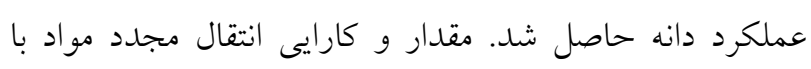
استفاده از معادلههاى ( ا و Y) محاسبه شدند (Yo) (Y). =مقدار انتقال مجدد (ميلى گرم در بوته) وزن خشك كل كَياه در زمان رسيدگى - حداكثر وزن خشك (زمان مهانها

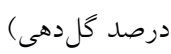

= كـــارايى انتقـــال=

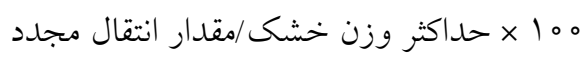

در پِايان تجزيه و تحليل دادهها بـا اسـتفاده از نــرمافـزار آمـارى SAS

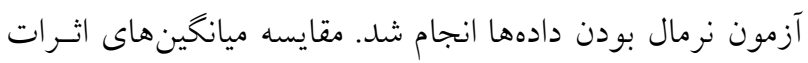

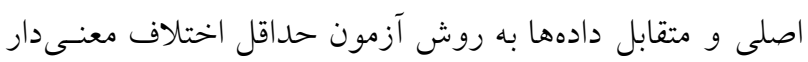

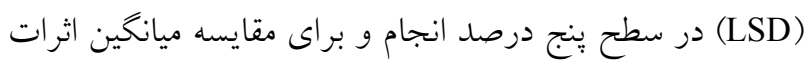




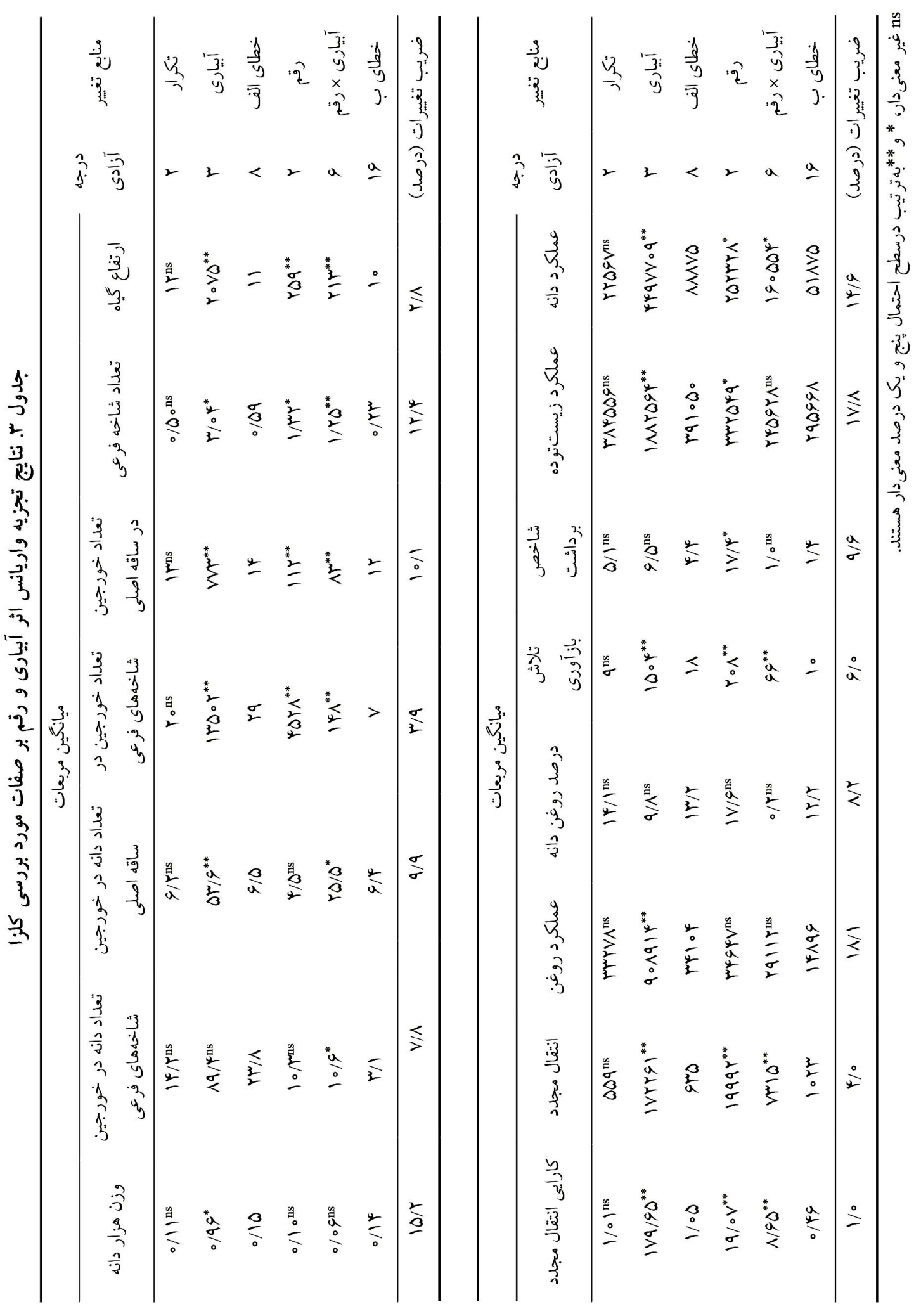




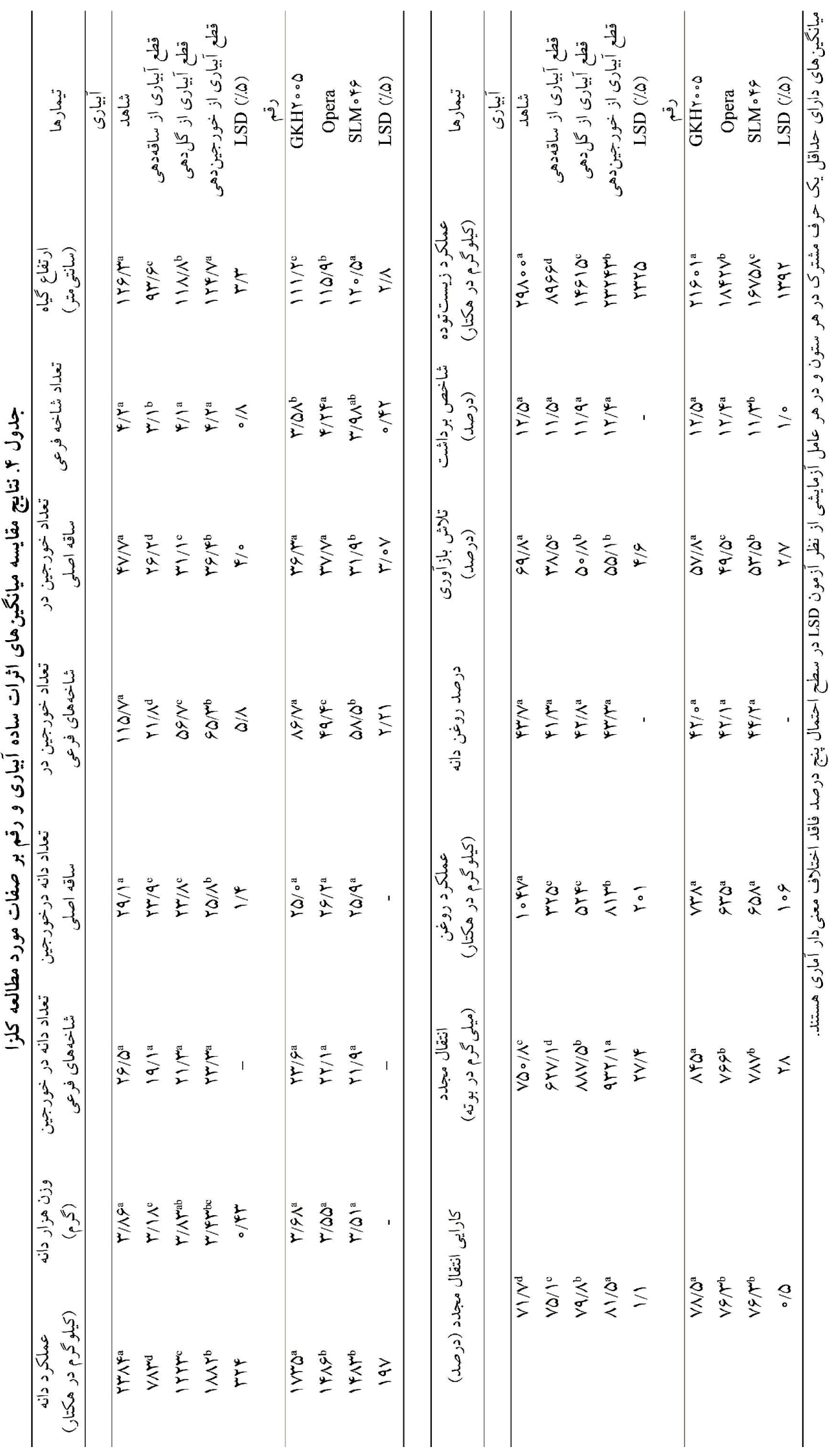




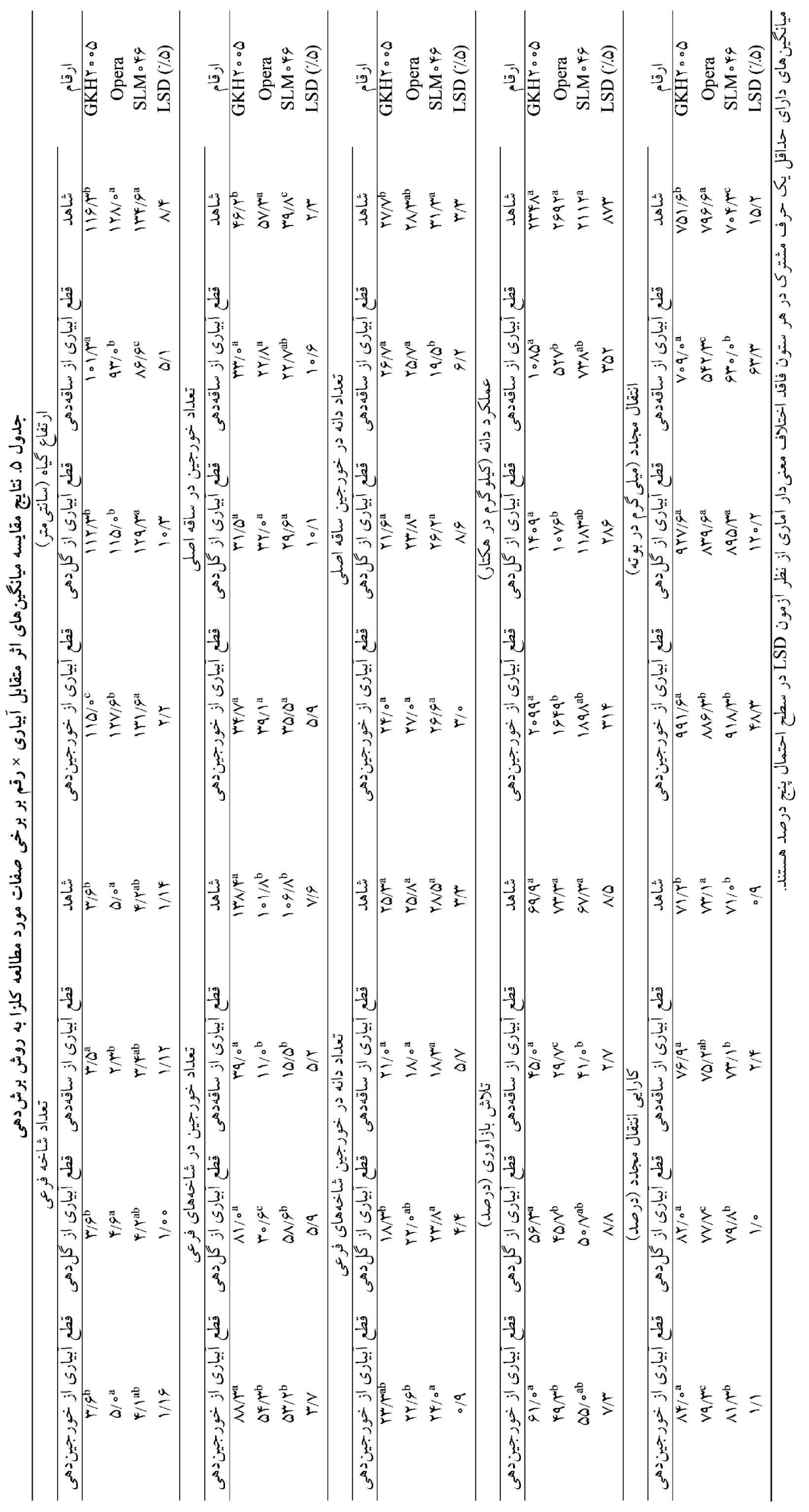


شاخههاى فرعى در مقايسه با دو رقم SLM०4 و بهويزه Opera

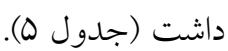

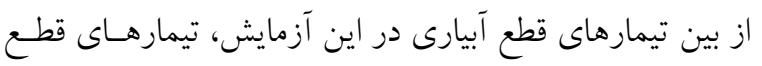

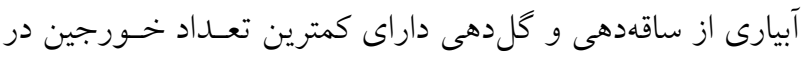

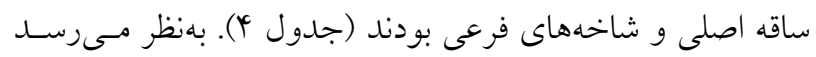

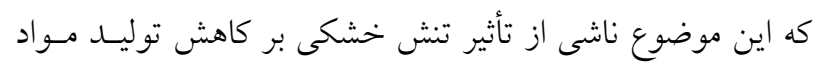

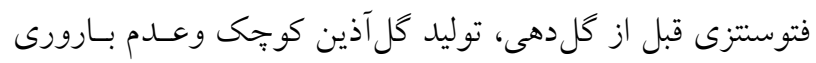

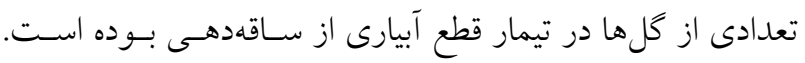

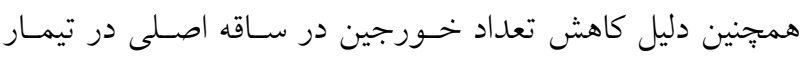

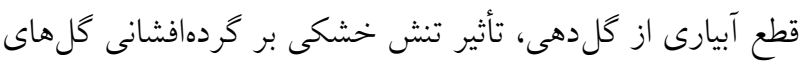

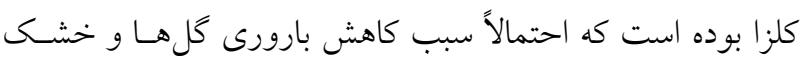
شدن آنها شده است. اين موضوع در مورد ساقه اصلى نسـبت بــهـ

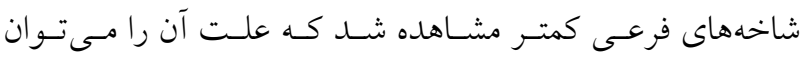

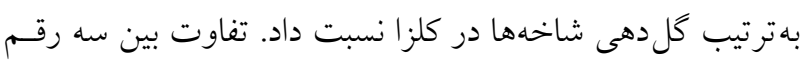
كلزاى مورد بررسى در سطوح مختلـف آبيـارى از نظـر تعـداد

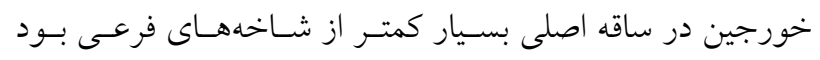

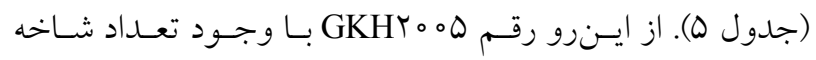

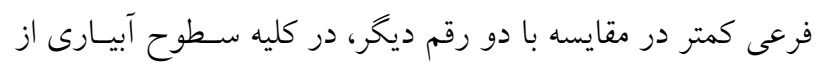

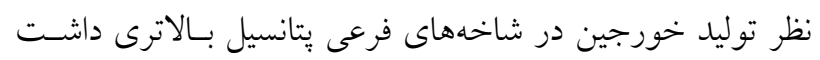

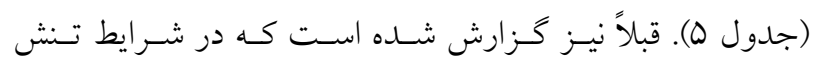

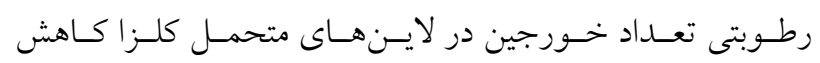

معنى دارى نمىيابد (آم).

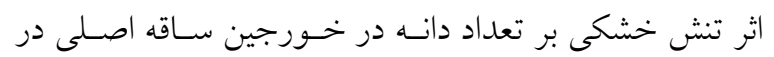

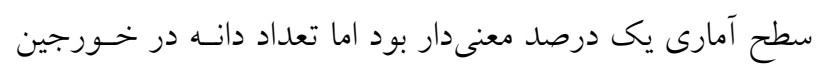

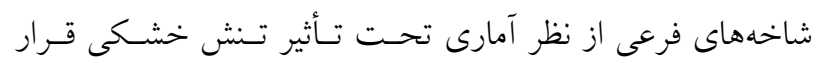

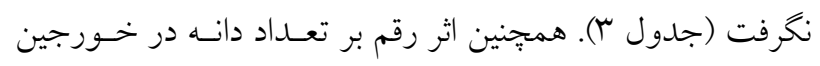

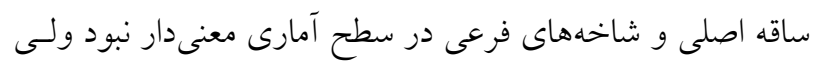

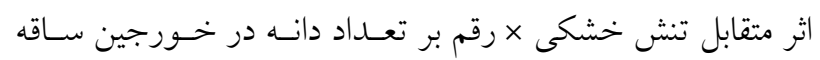

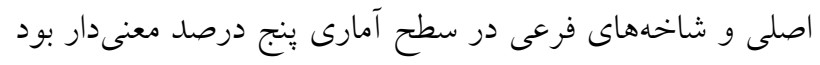

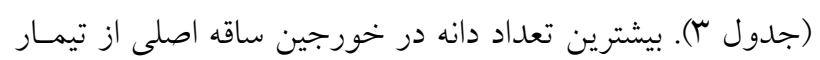

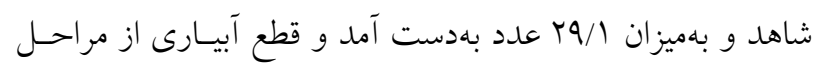
ساقهدهى و كل دهى سبب بيشترين كاهش اين صفت (بـهترتيـب
خورجيندهى بهدست آمد (بين / / تا ب/ عدا عدد) و قطع آبيـارى

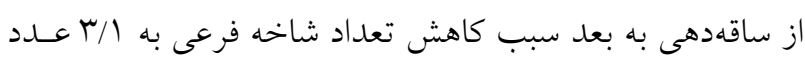

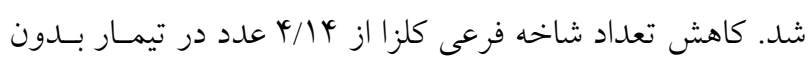

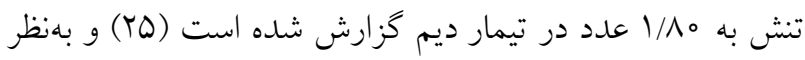

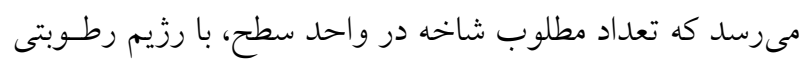
خاك در طى دوره رشد گياه ارتباط نزديكى دارد.

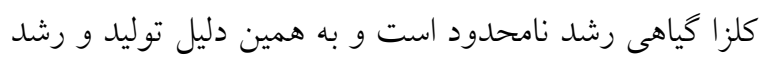

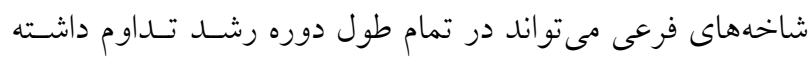

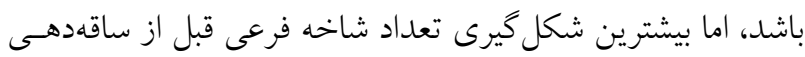

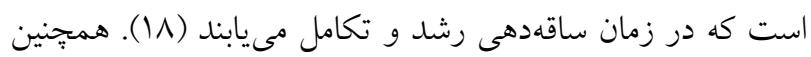
تعداد شاخه فرعى در رقم GKHY。oه در سطوح مختلـف تيمـار

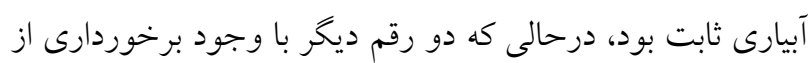
بيشترين تعداد شاخه فرعى در شرايط شاهد، با كاهش نسبتاً زيـاد

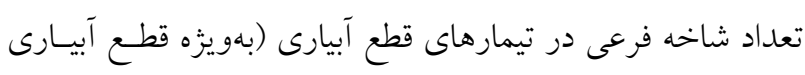

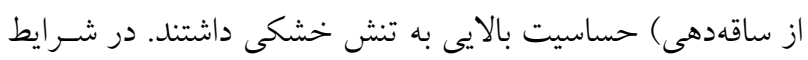

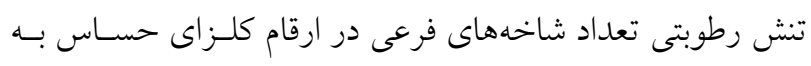

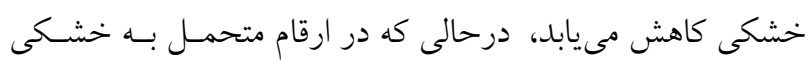

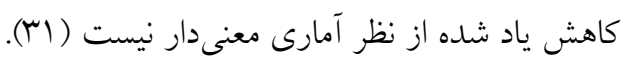

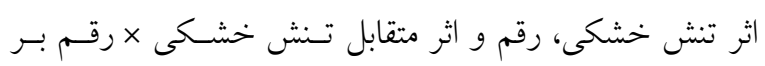

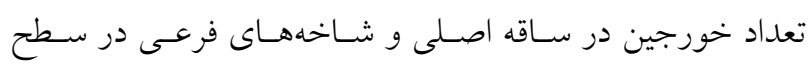

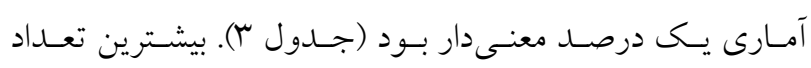

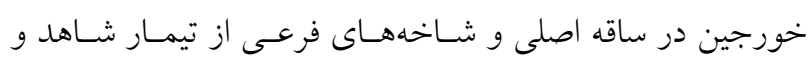

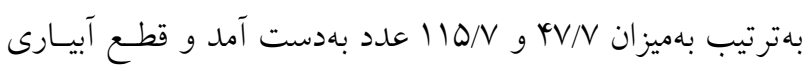

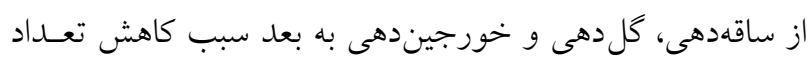

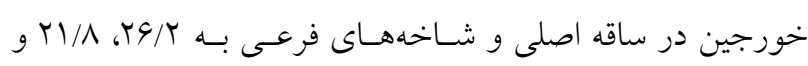

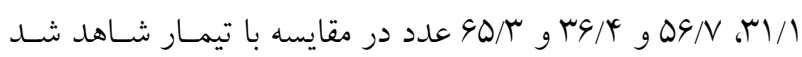

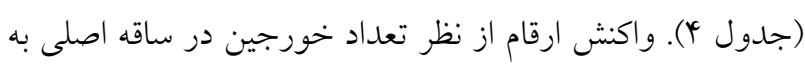

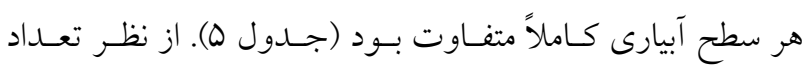

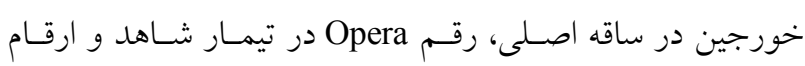

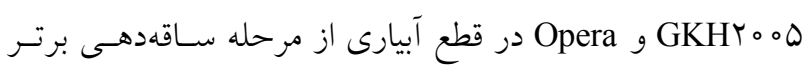

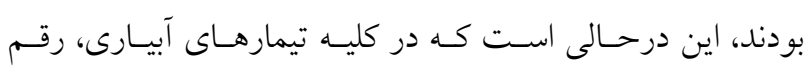

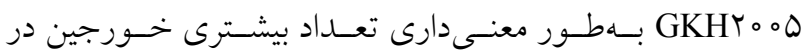


خورجينهاى شاخههـاى فرعى را داشـته و كـاهش معنسىدارى

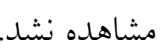
اثر تنش خشكى بر وزن هزار دانه در سطح آمارى ينج درصد معنى دار بود، درحالى كه اثر رقم و اثر متقابل تنش خشكى × رقـم بر اين صفت معنى دار نبود (جدول س). بيشترين وزن هزار دانسه از

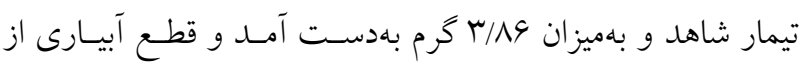
مراحل ساقهدهى، گل گدهى و خورجيندهى بهترتيب سبب كـاهش

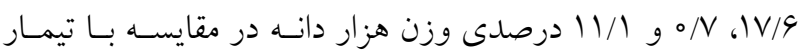
شاهد شد (جدول ץ). نتايج نشان داد كه در ميان تيمارهـاى قطع آبيارى، بيشترين ميزان كاهش وزن هزار دانـه در قطـع آبيـارى از ساقهدهى و خورجيندهى مشاهده شد، درحالى كه قطع آبيارى از كلدهى تأثير معنى دارى بر وزن هـزار دانـه نداثـت (جــدول ؟).

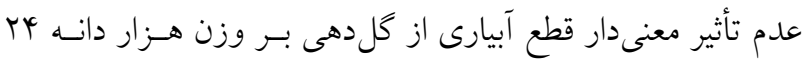
زنوتيب كلزا گزارش شده است كه با نتايج اين آزمايش همخوانى دارد (V). بهنظر مىرسد تنش خشكى از مرحله ساقهدهى احتمـالاً بــهواسـطه اخـتلال در فتوسـتنز كيـاه و در نتيجـهـ كـاهش سـتنز آسيميلات هاى لازم براى بــر شــن دانـهــا، و تــش خشـكى از مرحله خورجيندهى بهدليل همزمانى رشد دانـه بـا زمـان اعمـال تنش و اختلال در انتقال آسـيميلاتهــاى توليــ شــده در قبـل از كلدهى، جروو كيدگى و كاهش وزن دانهها را موجب شده است. در اين آزمايش اثر تنش خشكى بـر عملكـــد دانسه در سـطح

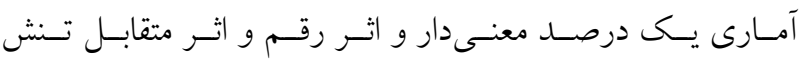
خشكى × رقم در سطح آمارى ينج درصد معنى دار بـود (جــدول

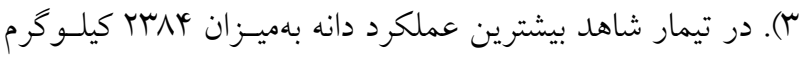
در هكتار توليد شد و با قطع آبيارى از مراحل ساقهدهى، گلدهـى و خورجيندهى، اين صفت بهترتيب بهميزان \&V، و \& و اب درصد كاهش يافت (جدول Y). همجنين ارقام در تيمـار شـاهد، تفـاوت معنى دارى با هم نداشتند، درحالى كه در قطـع آبيـارى از مراحـل

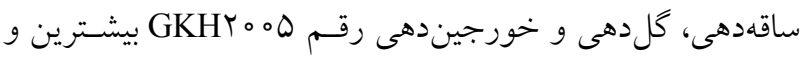
رقم Opera كمترين عملكرد دانه را توليد كردند (جدول ه). ايسن

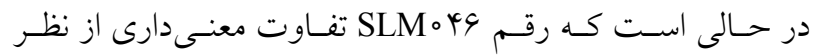
عملكرد دانه با ارقام هـ GKHYو Opera نداشـت (جـدول ه).
IV/N و IN/T درصد) در مقايسه با تيمار شاهد شد، در حسالىكـه اين ميزان كاهش در تيمار قطع آبيارى از خورجيندهـى برابـر بــا א/11 درصد بود (جدول (†). ارقام از نظر تعداد دانه در خورجين ساقه اصلى در هر سـطح آبيـارى متفــاوت بودنــد، بـهــــوان مثـال در تيمـار شــاهد رقـم

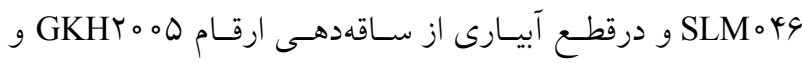
Opera كردنــ، امـا در تيمارهــاى قطـع آبيـارى از مراحـل گـلـدهـى و خورجيندهى تفاوت معنى دارى بين سه رقم كلزاى مورد بررسى مشــاهده نشــد (جـــول ه). از نظــر تعـداد دانـهـ در خــورجين شاخههاى فرعى، برخلاف تعداد دانه در خـورجين سـاقه اصـلى، ارقام اختلاف معنسى دارى در تيمارهـاى شـاهد و قطـع آبيـارى از ساقهدهى نداشتند، درحالى كه در تيمارهاى قطع آبيارى از مراحل كلدهى و خورجيندهى رقم SLM०4 برتر از دو رقم ديخر بود

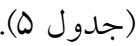

در اين آزمايش قطع آبيارى از ساقهدهى، احتمـالاً بـهواسـطه كاهش تعداد برگ و سطح برگ، مواد فتوسنتزى سـاخته شــه در برگها قبل و بعد از گل دهى را بهشــت كـاهش داده و بـهدليـل رقابت بين مخازن (دانهها) براى بر شدن، دانههـاى زيـادى بـوى ليـ مانده و يا سقط شدهاند. ايسن درحسالى اسـت كـه در تيمـار قطع آبيارى از كل دهى، احتمالاً كم شدن دوره فعاليت منبع (بـرگهـا) بهدليل تسريع در بيرى آنها و كاهش ميزان فتوسنتز جارى، قدرت مخزن در جذب مواد فتوسنتزى كاهش يافته است و ايسن عوامـل بههمراه بارور نبودن دانههاى گـرده و سـقط دانسهــا سـبب افـت تعداد دانه در خورجين در ساقه اصلى شده است. نتايج حاصله از اين آزمايش در تطابق با نتايج ديخر يزوهشخران است (V). نتسايج

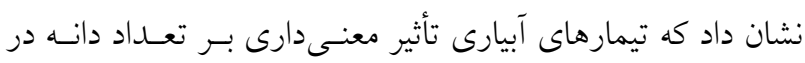
خورجين شاخههاى فرعى نداشته است كه اين موضوع به كـاهش شديد مشاهده شده در تعداد خورجين در شـاخههـاى فرعى در تيمارهاى قطع آبيارى مرتبط اسـت. از ايسنرو آسـيميلات توليـد شده در تيمارهاى قطع آبيارى با وجود كـاهش نسـبت بـه تيمـار بــدون تسـش (شـاهد)، توانـايى يــر شـدن دانسههـاى موجــود در 


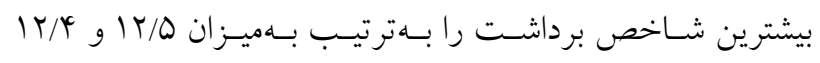
درصد دارا بودند و رقم SLM०4 شاخص برداشـت يـايينتـرى

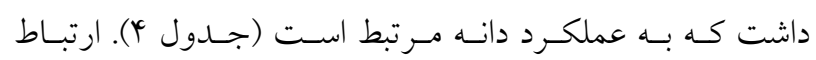
معنى دارى بين شاخص برداشـت و عملكـرد دانـه در كيـاه كلـزا

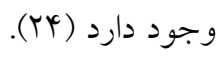

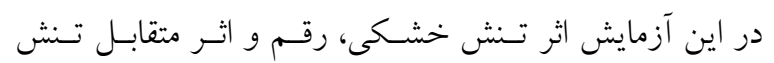

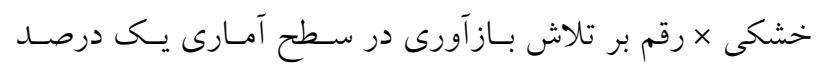
معنى دار بود (جدول r). در بين تيمارهـاى آبيـارى تيمـار شـاهد

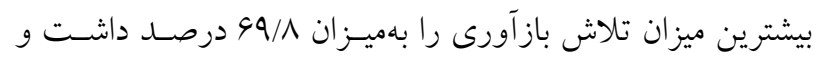
يس از آن تيمارهـاى قطـع آبيـارى از مراحـل خــورجيندهـى و

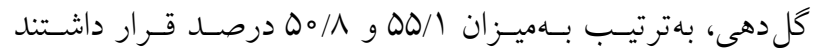
(جدول \&). همجنين كمترين ميزان تلاش باز آورى از تيمـار قطـع آبيارى از ساقهدهى بهميزان ه/N/ درصد حاصل شــ (جـدول ثا). همجِين در تيمار شاهل، سه رقم مورد بررسى تفاوت معنسى با هم نداشتند، درحالى كه در تيمارهاى قطع آبيارى از ساقهدهـى، كادهى و خورجيندهى رقم هـ GKHYم بيشترين ميـزان تـلاش

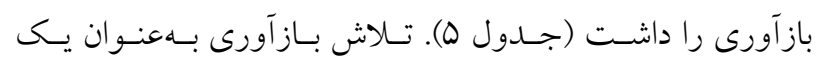
شاخص، معيارى از كارايى انتقال مو اد فتوسـتزى توليــ شــه در كياه به اندام زايشى (خورجينها) است (ها) و در اين آزمايش بر اساس نتايج حاصل مىتوان نتيجه كرفت كه تأثير تيمارهاى تـنش

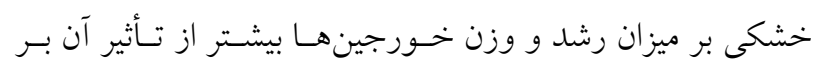

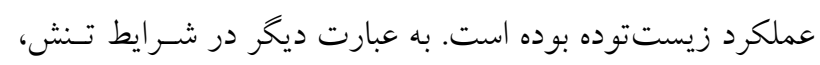
تسهيم مواد فتوسنتزى به اندام رويشى نسبت به اندام زايشى گيـاه كلزا غالبيت بيدا مى كند (19). عملكرد گياهان زراعى تحت شرايط تنش خشـكى بـهـــــ وابسته به فرايندهاى تسهيم ماده خشك بـه انــامهـاى زايشسى و رويشى است كه در ارقام و شرايط مختلف محيطى متفاوت است

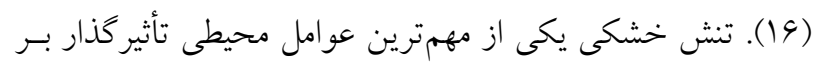

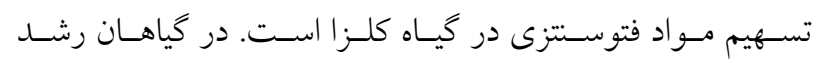
نامحدود مانند كلزا بهدليل همزمانى رشد زايشى با رشد رويشس، بين اندامها در جذب مواد فتوسنتزى رقابـت وجـود دارد و تـنش خشكى در مراحل كلدهى و توسعه خـورجينهـا بـر تخصسيص
كاهش عملكرد دانـه كلـزا در شـرايط تـش خش خشكى و خشكى توسط بسيارى از يزوهشخران كزارش شده است كه با نتـايج ايسن آزمايش همخوانى دارد (V و و Y). نتايج نشان داد كه قطع آبيـارى از مرحله ساقهدهى بهترتيب با كـاهش هף و 11 درصـدى تعـداد

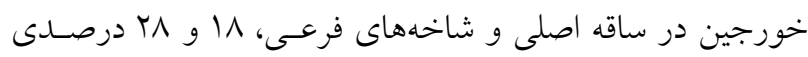
تعداد دانه در خورجين سـاقه اصسلى و شـاخههـاى فرعى و 11 درصدى وزن هزار دانه در مقايسه با تيمـار شـاهد سـبب كـاهش بيشتر عملكرد دانه در مقايسه با تيمارهاى قطع آيـارى از مرحلـه كلدهى و خورجيندهى شد (جدول \&)). اين در حالى اسـت كـه ميزان كاهش ذكـر شــه در تعـداد خـورجين در سـاقه اصـلى و شاخههاى فرعى، تعداد دانه در خورجين ساقه اصلى و شاخههاى فرعى و وزن هزار دانه در تيمار قطع آبيارى از مرحلـه خـلدهـى

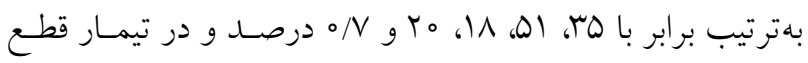

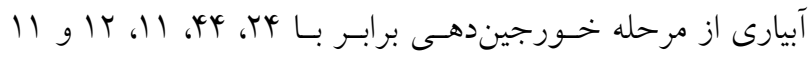
درصد بود (جدول †). عملكرد كياه كلزا تابع تعداد خـورجين در كياه، تعداد دانه در خورجين و وزن دانسهاسـت (با). بـالا بــودن

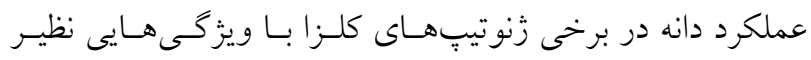

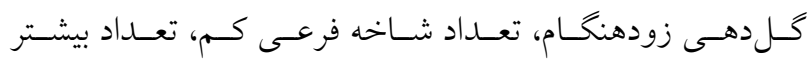
خورجينها، دانه در خورجين و وزن هزار دانه زياد مـرتبط اسـت

در اين آزمايش اثر تنش خشكى بر عملكـــد زيستـتـوده در

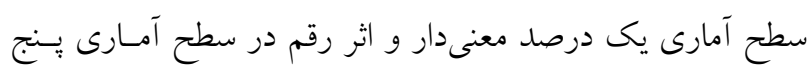
درصد معنى دار بود در حالى كه اثر متقابل تنش خشكى × رقـم در

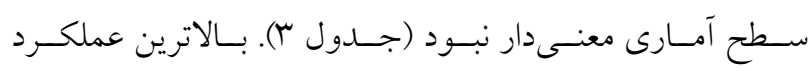

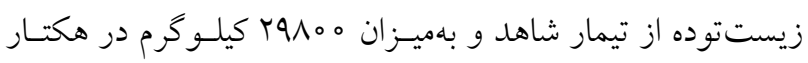

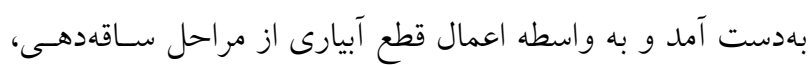
كل دهى و خورجيندهى ميانخين عملكرد زيست تـوده بـهـترتيـب

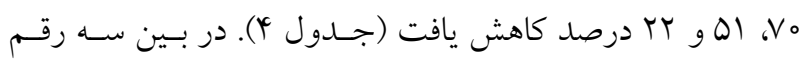

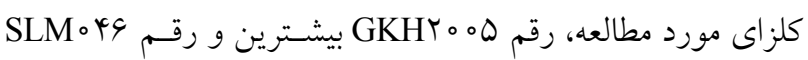
كمترين عملكرد زيست توده را داشت (جدول ثا). در ميان اثرهاى اصلى و متقابل، شاخص برداشت تنهـا تحـت

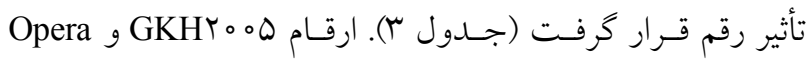


خشكى × رقم بـر انتقــال مجــد در سـطح آمـارى يـى درصــ

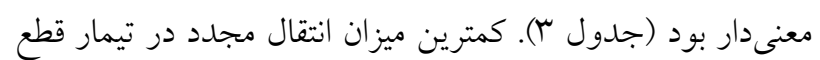

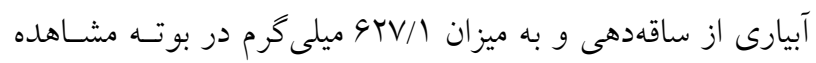

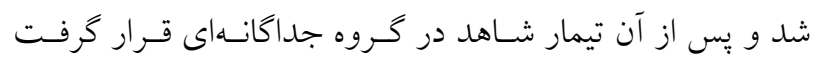

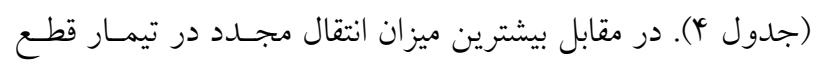

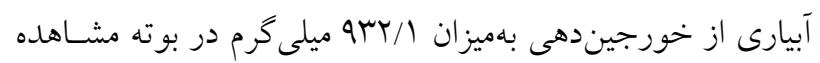

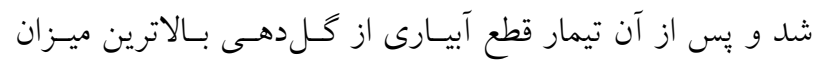

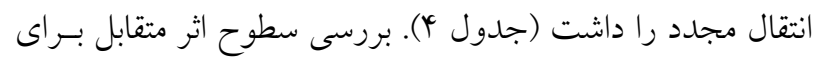
صفت انتقال مجدد نشان داد كه در تيمار شاهد، رقم Opera و در

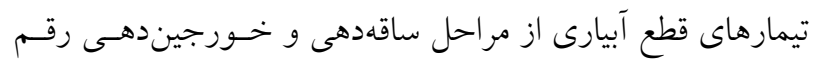

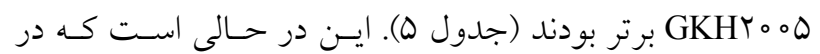

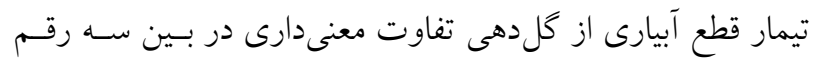

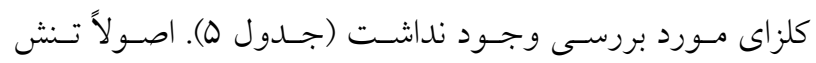

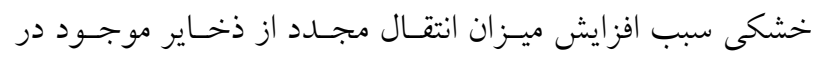

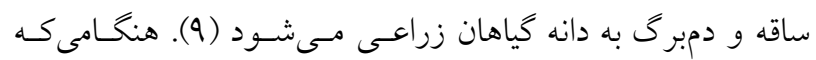

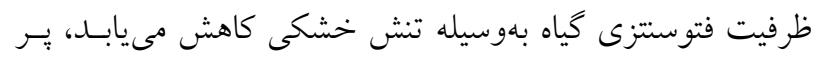

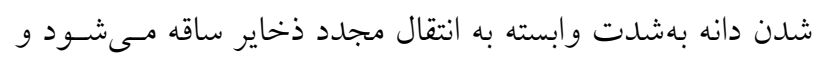

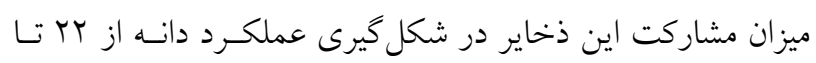

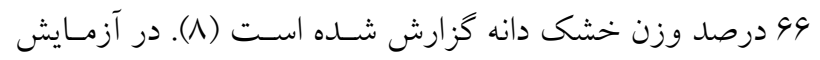

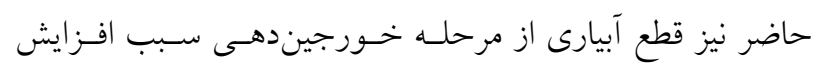

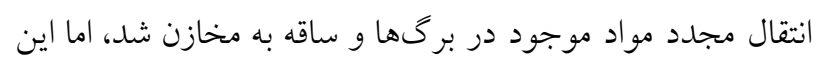

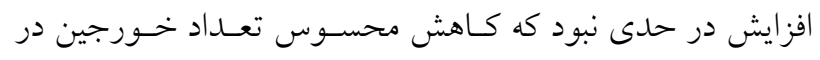

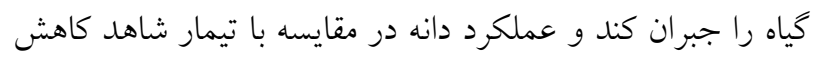

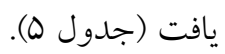
نتايج مندرج در جــدول ه بيـانخر ايسن موضـوع بـود كـه در

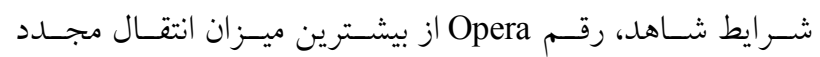

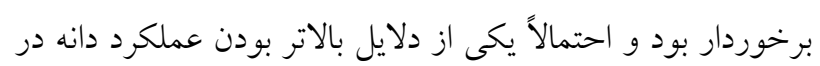

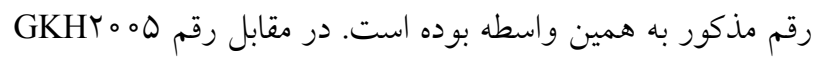

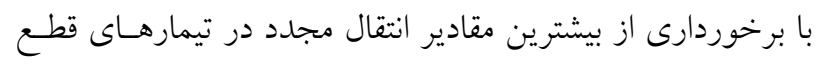

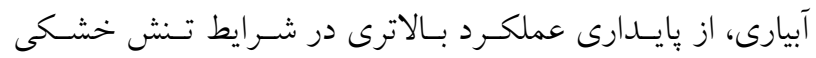
برخوردار بود (جدول ه). همخينين بهنظر مىرسد يكى از دلايـل بالاتر بودن تعداد خورجين در ساقه اصلى و شاخههاى فرعى در
مواد فتوسنتزى بين اندامهاى زايشى و رويشى اثر مى كذارد (YV).

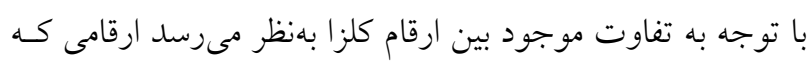

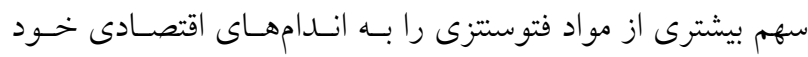

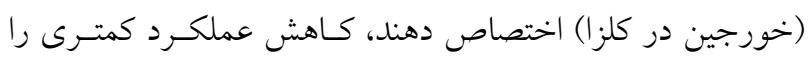

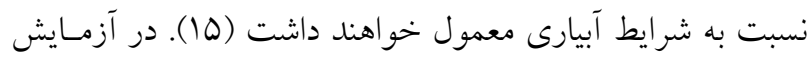

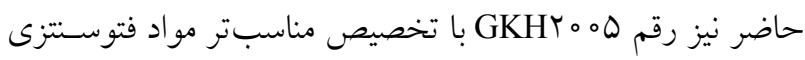

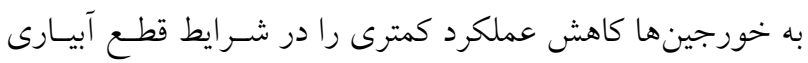

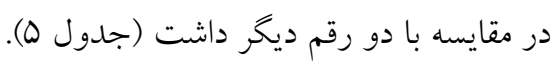

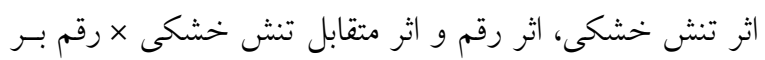

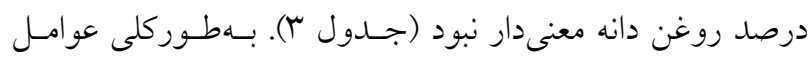

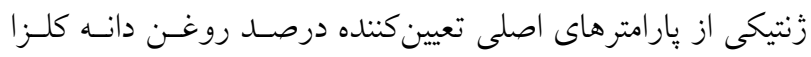

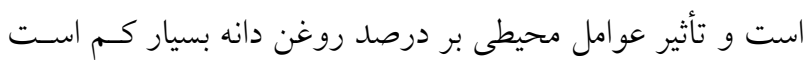

اثر تنش خشكى بر عملكرد روغن دانه در سطح آمـارى يـك

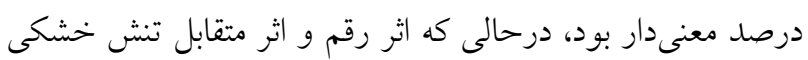

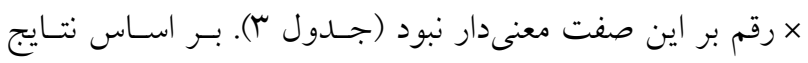

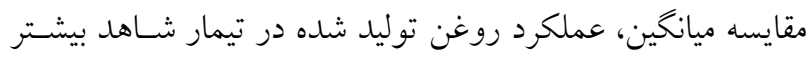

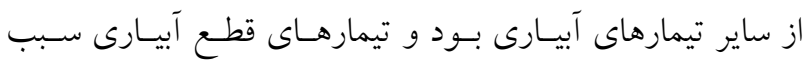

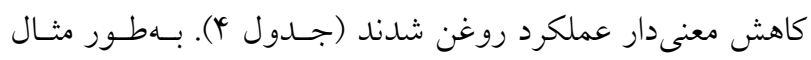

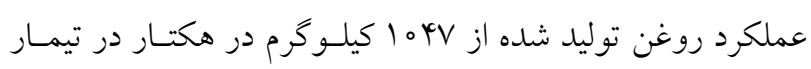

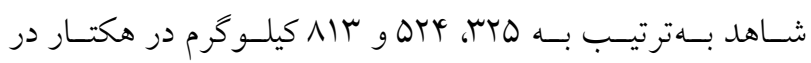

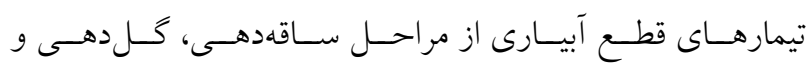

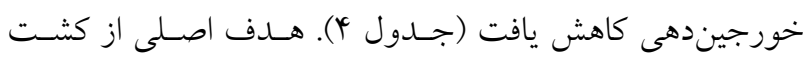

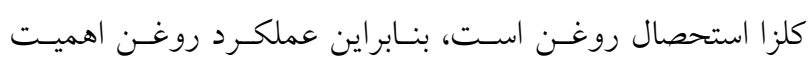

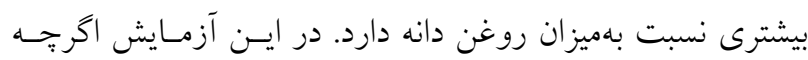

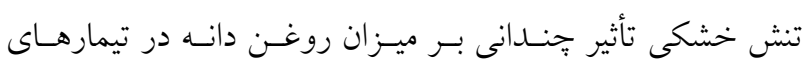

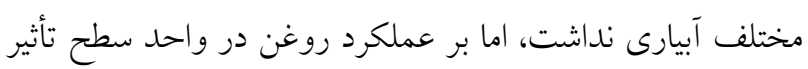

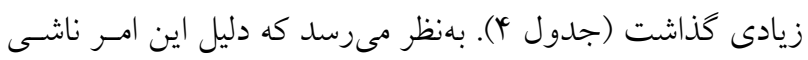

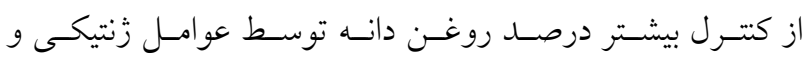

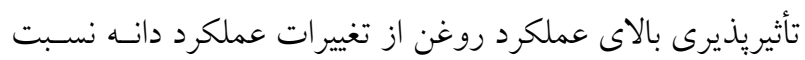
به درصل روغن بوده است. در اين آزمايش اثر تنش خشكى، اثر رقم و اثـر متقابـل تسنش دوصن 


$$
\begin{aligned}
& \text { آبيارى توانست عملكرد دانه بالاترى در مقايسه با دو رقم ديخـر } \\
& \text { رقم هـهKHY، GKHبالاتر بودن ميزان انتقال مجــد در رقــم مـذكور } \\
& \text { توليد كند (جدول ه). در اين زمينه نيز كزارش شـده اسـت كـه } \\
& \text { باشد. يزوهشخران ديخر نيز نيز بر نقش مهم انتقال مجدد در بالاتر } \\
& \text { با اعمال قطع آبيارى از مرحله گردهافشانى، ميزان انتقال مجدد و }
\end{aligned}
$$

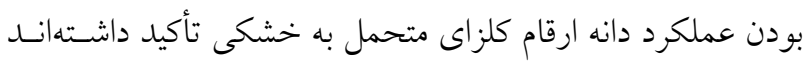

$$
\begin{aligned}
& \text { كارايى انتقال مجدد بهترتيب ها و ه ها درصد نسـبت بـه تيمسار } \\
& \text { آبيارى كامل افزايش يافت (11). } \\
& \text { نتيجه كيرى } \\
& \text { در اين آزمايش اثر تنش خشكى، اثر رقم و اثر متقابل تـنش }
\end{aligned}
$$

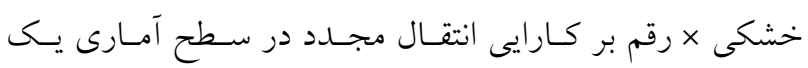

$$
\begin{aligned}
& \text { درصد معنى دار بود (جدول س)). بيشترين و كمترين ميزان كارايى } \\
& \text { انتقال مجدد بهترتيب در تيمارهاى قطع آبيارى از خورجيندهى }
\end{aligned}
$$

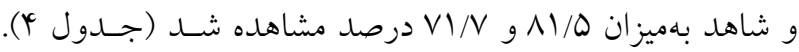

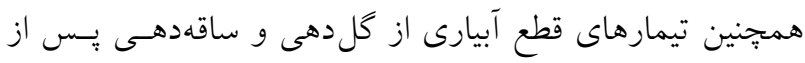

$$
\begin{aligned}
& \text { تيمار قطع آبيارى از خورجيندهى، بيشترين كارايى انتقال مجدد } \\
& \text { را داشتند و كارايى انتقال مجدد در تيمارهاى مذكور در مقايسـه }
\end{aligned}
$$

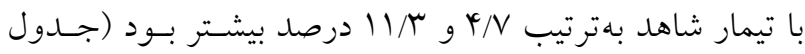

$$
\begin{aligned}
& \text { †). واكنش سه رقم كلزاى مورد بررسىى از نظـر كـارايى انتقـال } \\
& \text { مجدد بسيار متفاوت بود، بهطورى كه در شرايط بدون تنش رقم } \\
& \text { بpera } \\
& \text { انتقال مجدد نيز بسيار كارآمد بود. ايسن در حسالى اسـت كـه در } \\
& \text { سطوح تنش خشكى رقم Opera در انتقال مجـدد مـواد ذخيـره } \\
& \text { شده در مخازن ثانويه (ساقه و دمبرى) كارايى زيادى نداشـت و } \\
& \text { عملكــرد دانــه كمسى توليـــ كـرد (جــول ه). در مقابـل رقـم } \\
& \text { هKHY。oه با كارايى بالا در انتقال مجدد به موازات اعمال قطع }
\end{aligned}
$$

\section{منابع مورد استفاده}

1. Abid, M., Z. Tian, S. T. Ata-Ul-Karim, Y. Liu, Y. Cui, R. Zahoor, D. Jiang and T. Dai. 2016. Improved tolerance to post-anthesis drought stress by pre-drought priming at vegetative stages in drought-tolerant and -sensitive wheat cultivars. Plant Physiology and Biochemistry 106: 218-227.

2. Akhzari, D. and M. Pessarakli. 2015. Effect of drought stress on total protein, essential oil content, and physiological traits of levisticum officinale koch. Journal of Plant Nutrition 39(10): 1365-137.

3. Angadi, S. V. and M. H. Entz. 2002. Root system and water use patterns of different height sunflower cultivars. Agronomy Journal 94: 136-145.

4. Bahari, N. and H. Shahbazi. 2011. Remobilization of stem reserves in some bread wheat cultivars under normal and terminal drought stress. Advances in Environmental Biology 5(8): 24-34.

5. Bannayan, M., S. Sanjani, A. Alizadeh, S. Lotfabadi and A. Mohammadian. 2010. Association between climate indices, aridity index, and rainfed crop yield in northeast of Iran. Field Crops Research 118(2):105-114.

6. Bert, P. F., I. Jouan, D. Tourvieille de Labrouhe, F. Serre, J. Philippon, P. Nicolas and F. Vear. 2003. Comparative genetic analysis of quantitative traits in sunflower (Helianthus annuus L.). 2. Characterization of QTL involved in developmental and agronomic traits. Theoretical and Applied Genetics 107: 181-189.

7. Bitarafan, Z. and A.H. Shirani Rad. 2012. Water stress effect on spring rapeseed cultivars yield and yield components in winter planting. International Journal of Physical Science 7(19): 2755-2767. 
8. Blum, A., J. Sinmena, G. Mayer and L. Shpiler. 1994. Stem reserve mobilization supports wheat grain filling under heat stress. Australian Journal of Plant Physiology 21: 771-781.

9. Blum, A. 1998. Improving wheat grain filling under stress by stem reserves mobilization. Euphytica 100: $77-83$.

10. Diepenbrock, W. 2000. Yield analysis of winter oilseed rape (Brassica napus L.): a review. Field Crops Research 67: 35-49.

11. Ezzat Ahmadi, M., G. Noormohammadi, M. Ghodsi and M. Kafi. 2011. Effect of water stress and source limitation on accumulation and remobilization of photoassimilates in wheat genotypes. Iranian Journal of Field Crops Research 9 (2): 229-241. (In Farsi).

12. Fleta-Soriano, E. and S. Munné-Bosch. 2016. Stress memory and the inevitable effects of drought: A physiological perspective. Frontiers in Plant Science 7: 143.

13. Gent, M. P. N. 1994. Photosynthate reserves during grain filling in winter wheat. Agronomy Journal 86: $159-167$.

14. Ghobadi, M., M. Bakhshandeh, G. Farhi and M. H. Gharineh. 2006. Short and long period of water stress during different growth stage of canola (Brassica naps L.) effect on yield components, seed oil and protein contents. Agronomy Journal 5(2): 336-341

15. Jabbari, H., G. A. Akbari, J. Daneshian, I. Allahdadi and N. Shahbazian. 2007. Effect of water deficit stress on agronomic characteristics of Sunflower hybrids. Journal of Agriculture 9(1): 13-22. (In Farsi).

16. Kage, H., M. Kochler and H. Stutzel. 2004. Root growth and dry matter partitioning of cauliflower under drought stress conditions: measurement and simulation. European Journal of Agronomy 20: 379-394.

17. Kobata, T., J. A. Palta and N. C. Turner. 1992. Rate of development of post anthesis water deficits and grain filling of spring wheat. Crop Science 32: 1238-1242.

18. Meier, U. 2001. Growth Stages of Mono and Dicotyledonous Plants (BBCH Monograph). Federal Biological Research Centre for Agriculture and Forestry, Germany.

19. Monjem, S., A. V. Ahmadi and A. Mohamadi. 2011. Effects of drought stress in Reproductive Stages on photoassimilates partitioning of Rapeseed (Brassica napus). Electronic Journal of Crop Production 3(3): 163-178. (In Farsi).

20. Mostafavi Rad, M. and A. Mir Abdulhagh Hezavei. 2011. Effects of seeding rate on important agronomic traits in three winter Rapeseed (Brassica napus L.) cultivars. Iranian Journal of Field Crop Science 41(4): 685-697. (In Farsi).

21. Qian, W., Q. Li, J. Noack, O. Sass, J. Meng, M. Frauen and C. Jung. 2009. Heterotic patterns in rapeseed (Brassica napus L.): II. Crosses between European winter and Chinese semi-winter lines. Plant Breeding 128 (5): $466-470$.

22. Rashidi, S., A. H. Shirani Rad, A. Ayene Band, F. Javidfar and S. Lak. 2012. Study of relationship between drought stress tolerances with some physiological parameters in canola genotypes (B. napus L.). Annals of Biological Research 3 (1): 564-569.

23. Robertson, M. J. and J. F. Holland. 2004. Production risk of canola in the semi-arid subtropics of Australia. Australian Journal of Agricultural Research 55: 525-538.

24. Sadaqat, H. A., M. H. Nadeem Thahir and M. T. Hussain. 2003. Physiogenetics aspects of drought tolerance in canola. International Journal of Agriculture and Biology 5: 611-614.

25. Shabani, A., A. A. Kamkar Haghighi, A. R. Sepaskhah, Y. Emam and T. Honar. 2011. Effect of water stress on grain yield, yield components and quality of winter rapeseed (Brasica napus L.) cv. Licord. Iranian Journal of Crop Sciences 12(4): 409-421. (In Farsi).

26. Sharghi, Y., A. H. Shirani Rad, A. Ayeneh Band, G. Noormohammadi and H. Zahedi. 2011. Yield and yield components of six canola (Brassica napus L.) cultivars affected by planting date and water deficit stress. African Journal of Biotechnology 10 (46): 9309-9313.

27. Sinaki, J. M., E. Majidi Heravan, A. H. Shirani Rad, G. Noormohamadi and G. Zarei. 2007. The effects of water deficit during growth stages of canola (B. napus L.). American-Eurasian Journal of Agricultural \& Environmental Sciences 2(4): 417-422.

28. Sun, X. P., H. L. Yan, X. Y. Kang and F. W. Ma. 2013. Growth, gas exchange, and water-use efficiency response of two young apple cultivars to drought stress in two scion-one rootstock grafting system. Photosynthetica 51(3): 404-410.

29. Svensk, H. 1979. Breeding for increased yield in double-row spring rapeseed. In: Proceeding of the $5^{\text {th }}$ International Rapeseed Conference. Malmö, Sweden. pp. 84-86 .

30. Wardlaw, I. F. and J. Willenbrink. 2000. Mobilization of fructan reserves and changes in enzyme activities in wheat stems correlate with water stress during kernel filling. New Phytologist 148: 413-422.

31. Zakirullah, Z., Z. A. Swati, A. Ahamd and R. Raziuddin. 2000. Morpho-physiological response of selected brassica line to moisture stress. Pakistan Journal of Biological Sciences 3(1): 130-132. 


\title{
Evaluation of the Dry Matter Remobilization to Seeds in Winter Rapeseed Cultivars under Drought Stress Conditions
}

\author{
H. Jabbari ${ }^{*}$, N. A. Khosh kholgh Sima², Gh. A. Akbari ${ }^{3}$ and A. H. Shirani rad ${ }^{4}$
}

(Received: August 14-2017; Accepted: July 14-2019)

\begin{abstract}
In order to evaluate dry matter remobilization to seeds in the winter type rapeseed cultivars grown under drought stress conditions, an experiment was carried out using a randomized complete block design arranged in a split plot with three replicates in Shahre-Qods, Iran, in the 2011-2012 growing season. Irrigation treatments including control (irrigation after $80 \mathrm{~mm}$ evaporation from evaporation pan class A) and drought stress (irrigation withholding starting from stem elongation, flowering and silique formation stages) were allocated to the main plots and three winter type rapeseed cultivars (GKH2005, Opera and SLM046) were considered as the subplots. The results showed that drought stress increased dry matter remobilization and remobilization efficiency. By contrast, agronomic traits such as the number of siliques on the main stem and secondary branches, number of seeds per silique, 1000 seed weight, oil yield, harvest index and productivity effort (silique dry weight/biomass ratio) were decreased. The GKH2005 cultivar showed the maximum seed yield, which was 1058, 1409 and $2099 \mathrm{~kg} \mathrm{ha}^{-1}$, when irrigation withholding started from stem elongation, flowering stage, and silique formation stages, respectively; this was due to the higher amount of remobilization and the efficiency of remobilization and maximum number of silique in the secondary branches. In general, the results suggest that higher remobilization and remobilization efficiency are among the most important drought stress tolerance mechanisms in the oilseed rape.
\end{abstract}

Keywords: Seed number, Seed yield, Silique number, Withholding irrigation

1, 4. Assistant Professor and Professor, Respectively, Seed and Plant Improvement Institute (SPII), Agricultural Research, Education and Extension Organization (AREEO), Karaj, Iran.

2. Associate Professor, Agriculture Biotechnology Research Institute of Iran (ABRII), Agricultural Research, Education and Extension Organization (AREEO), Karaj, Iran.

3. Associate Professor, Department of Agronomy and Plant Breeding, College of Aboureyhan, University of Tehran, Tehran, Iran.

*: Corresponding Author, Email: shenghar021@gmail.com 